\title{
Observation and analysis of speciated atmospheric mercury in Shangri-La, Tibetan Plateau, China
}

\author{
H. Zhang ${ }^{1,2}$, X. W. Fu ${ }^{1}$, C.-J. Lin ${ }^{1,3,4}$, X. Wang ${ }^{1,2}$, and X. B. Feng ${ }^{1}$ \\ ${ }^{1}$ State Key Laboratory of Environmental Geochemistry, Institute of Geochemistry, \\ Chinese Academy of Sciences, Guiyang 550002, China \\ ${ }^{2}$ University of Chinese Academy of Sciences, Beijing 100049, China \\ ${ }^{3}$ Department of Civil Engineering, Lamar University, Beaumont, Texas 77710, USA \\ ${ }^{4}$ College of Energy and Environment, South China University of Technology, \\ Guangzhou 510006, China
}

Correspondence to: X. B. Feng (fengxinbin@vip.skleg.cn)

Received: 26 March 2014 - Published in Atmos. Chem. Phys. Discuss.: 5 May 2014

Revised: 3 December 2014 - Accepted: 8 December 2014 - Published: 19 January 2015

\begin{abstract}
This study reports the concentrations and potential sources of speciated atmospheric mercury at the Shangri-La Atmosphere Watch Regional Station (SAWRS), a pristine high-altitude site (3580 m a.s.l.) in Tibetan Plateau, China. Total gaseous mercury (TGM, defined as the sum of gaseous elemental mercury, GEM, and gaseous oxidized mercury, GOM), GOM and particulate-bound mercury (PBM) were monitored from November 2009 to November 2010 to investigate the characteristics and potential influence of the Indian summer monsoon (ISM) and the Westerlies on atmospheric transport of mercury. The mean concentrations ( \pm standard deviation) of TGM, PBM and GOM were $2.55 \pm 0.73 \mathrm{ng} \mathrm{m}^{-3}, 38.82 \pm 31.26 \mathrm{pg} \mathrm{m}^{-3}$ and $8.22 \pm 7.90 \mathrm{pg} \mathrm{m}^{-3}$, respectively. A notable seasonal pattern of TGM concentrations was observed with higher concentrations at the beginning and the end of the ISM season. High TGM concentrations $\left(>2.5 \mathrm{ng} \mathrm{m}^{-3}\right)$ were associated with the transport of dry air that carried regional anthropogenic emissions from both Chinese domestic and foreign (e.g., Myanmar, Bay of Bengal, and northern India) sources based on analysis of HYSPLIT4 back trajectories. Somewhat lower PBM and GOM levels during the ISM period were attributed to the enhanced wet scavenging. The high GOM and PBM were likely caused by local photo-chemical transformation under low RH and the domestic biofuel burning in cold seasons.
\end{abstract}

\section{Introduction}

Mercury $(\mathrm{Hg})$ is a persistent toxic pollutant released to the atmosphere from both anthropogenic and natural sources (Pirrone et al., 1996; Pirrone et al., 2001; Carpi and Lindberg, 1998). Due to its volatility, gaseous elemental mercury (GEM) can be transported over a long distance. Hg interconverts among GEM, gaseous oxidized mercury (GOM) and particulate-bound mercury (PBM) and enters terrestrial and aquatic ecosystems in remote areas via dry and wet deposition (Johansson et al., 2001). Deposited Hg can be converted into methylmercury, a potent neurotoxin that bioaccumulates and biomagnifies in the food chain and causes severe public health concerns (Lindqvist, 1991; Sunderland et al., 2009). In the atmosphere, GEM is the predominant species and accounts for $>90 \%$ of total $\mathrm{Hg}$ (Iverfeldt and Lindqvist, 1986; Schroeder and Munthe, 1998). The global background of GEM is $1.5-1.7$ and $1.1-1.3 \mathrm{ng} \mathrm{m}^{-3}$ in the Northern and Southern Hemisphere, respectively. Typical concentrations of GEM, GOM and PBM measured at remote sites are in the ranges of $1-4 \mathrm{ng} \mathrm{m}^{-3}, 3-70 \mathrm{pg} \mathrm{m}^{-3}$ and $7-100 \mathrm{pg} \mathrm{m}^{-3}$, respectively (Valente et al., 2007; Pfaffhuber et al., 2012). In the Arctic, the GEM, PBM and GOM median concentrations are $1.6 \mathrm{ng} \mathrm{m}^{-3}, 11.3 \mathrm{pg} \mathrm{m}^{-3}$ and $3.2 \mathrm{pg} \mathrm{m}^{-3}$, respectively (Steffen et al., 2014). In Antarctica, the mean annual GEM concentration of $0.93 \pm 0.19 \mathrm{ng} \mathrm{m}^{-3}$ is in good agreement with recent southern hemispheric measurements (Pfaffhuber et al., 2012). 
Observations of atmospheric $\mathrm{Hg}$ are important for understanding its global biogeochemical cycle. Long-term and continuous measurements at remote sites are particularly valuable because such data help in understanding the seasonal trends and transport patterns of atmospheric $\mathrm{Hg}$ in a given region ( $\mathrm{Li}$ and Lee, 2014; Pirrone et al., 2010b; Driscoll et al., 2013). In addition, the observations provide data for constraining atmospheric models of $\mathrm{Hg}$. There have been ongoing efforts to establish monitoring networks, including the atmospheric mercury network (AMNet) in North America and the Global Mercury Observation System (GMOS) (Sprovieri et al., 2013; Gay et al., 2013). Monitoring of speciated atmospheric $\mathrm{Hg}$ at remote sites is challenging due to issues related to instrumental maintenance, accessibility to the sites and other logistic limitations. To date, the availability of speciated atmospheric $\mathrm{Hg}$ observations is inadequate for a thorough understanding of $\mathrm{Hg}$ chemical transport in different regions.

Shangri-La is located remotely in the southeastern corner of the Tibetan Plateau, which extends from 25 to $45^{\circ} \mathrm{N}$ and from 70 to $105^{\circ} \mathrm{E}$. This Plateau covers approximately onequarter of the land area in mainland China with a mean elevation of more than $4000 \mathrm{~m}$ a.s.l. Given the location between South and East Asia, the levels of air pollutants at Shangri$\mathrm{La}$ are potentially influenced by the two largest source regions in the world. There are an increasing number of studies highlighting the large and increasing $\mathrm{Hg}$ emissions in the fast-developing countries (Pirrone et al., 2010). China is the largest $\mathrm{Hg}$ emitter in the world, despite its continued effort in $\mathrm{Hg}$ emission reduction (Streets et al., 2005; Pacyna et al., 2006). India, with the world's fourth biggest coal reserve, is another rapidly growing economy whose $\mathrm{Hg}$ use and emission have been increasing over the past few decades (Sharma, 2003). Therefore, it is environmentally significant to better understand the transboundary transport of air pollutant emissions between China and India. Recent assessments suggested that the emissions in India are of global importance, especially to the Tibetan Plateau, where the long-range transport of black soot accelerates glacier melting (Xu et al., 2009). In addition, it has been reported that $\mathrm{Hg}$ emissions from South Asia can be transported to the Tibetan Plateau and deposited on glaciers through the Indian summer monsoon (ISM), which has led to higher $\mathrm{Hg}$ concentrations in snow packs (Loewen et al., 2007; Zhang et al., 2012). Hg emissions from the biomass burning in Southeast Asia also represent a significant yet uncertain regional source (Pirrone et al., 2010b). In light of these perspectives, Shangri-La appears to be a strategic observational site for studying the long-range transport of $\mathrm{Hg}$ emitted from these sources.

In this study, we report the characteristics of the speciated atmospheric Hg at the Shangri-La Atmosphere Watch Regional Station (SAWRS) and analyze the potential source regions that contributed to the observed concentrations. In particular, we assess the role of the ISM and the Westerlies in the long-range transport of $\mathrm{Hg}$. This study addresses

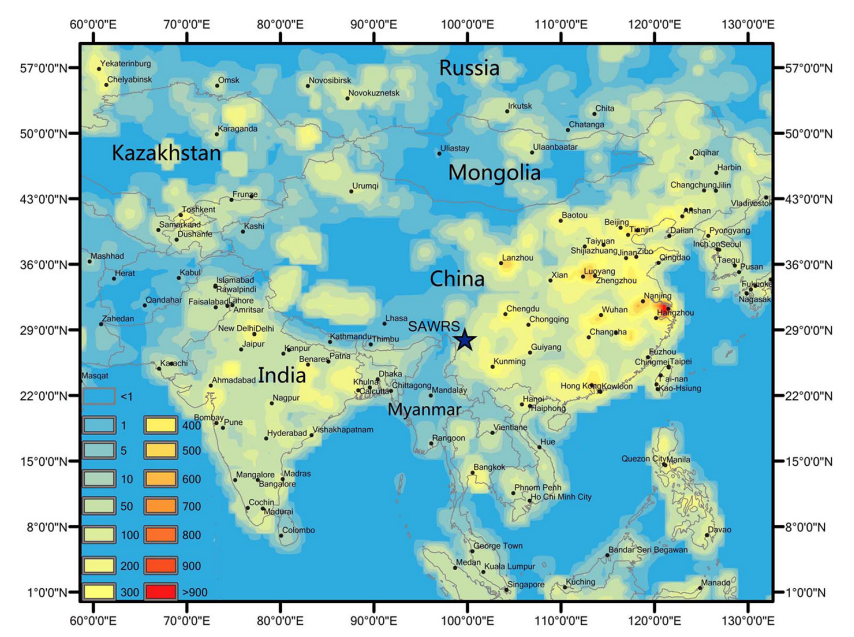

Figure 1. Map showing the location of SAWRS, anthropogenic $\mathrm{Hg}$ emissions $\left(\mathrm{g} \mathrm{km}^{-2} \mathrm{y}^{-1}\right)$ and major cities in Asia (AMAP/UNEP, 2013).

the GMOS objectives in establishing a global mercury monitoring network for ambient concentrations and deposition of $\mathrm{Hg}$ through ground-based observational platforms as well as oceanographic and aircraft campaigns. The data within the GMOS network can be used for model assessment, for understanding the global biogeochemical cycling of $\mathrm{Hg}$, and for establishing a global source-receptor relationship of Hg emissions. The program involves 24 partners around the world (GMOS, http://www.gmos.eu/).

\section{Materials and methods}

\subsection{Measurement site description}

Figure 1 shows the locations of SAWRS and major Asian cities. SAWRS $\left(28^{\circ} 01^{\prime} \mathrm{N}, 99^{\circ} 44^{\prime} \mathrm{E}\right.$; $3580 \mathrm{~m}$ a.s.l.) is a remote highland site located in the Hengduan Mountains area southeast of the Tibetan Plateau. The SAWARS, $\sim 30 \mathrm{~km}$ north of Shangri-La city, is near a mountaintop and surrounded by alpine forest. The largest point sources near SAWRS are coal-fired power plants in the city of Kunming, the capital of Yunnan province, which is $\sim 500 \mathrm{~km}$ to the southeast. Other large cities (Chengdu, Guiyang and Chongqing) are east of Shangri-La $(\sim 1000 \mathrm{~km})$. India and Bengal are located to the west of SAWRS and Southeast Asia (in this study, it is defined as the region with boundaries from 92 to $140^{\circ} \mathrm{E}$ and from $10^{\circ} \mathrm{S}$ to $23^{\circ} \mathrm{N}$ ). It has a cold and dry winter that lasts for 5 months from late October to April before the onset of the ISM. Its annual average temperature is $5.1^{\circ} \mathrm{C}$. The average temperature is $-1.4^{\circ} \mathrm{C}$ from December to February and $12.4^{\circ} \mathrm{C}$ from June to August (Table 1). The population density in Shangri-La is approximately 10 persons per square kilometer. There are no large-scale industrial activities and fossil fuel consumption in the area. Domestic biofuel burn- 
ing for cooking and house hold heating are the main emission sources, which release $<10 \mathrm{~g} \mathrm{~km}^{-2} \mathrm{y}^{-1}$ of $\mathrm{Hg}$ annually (AMAP/UNEP, 2013).

\subsection{Sampling methods and analysis}

\subsubsection{Measurements of atmospheric TGM, PBM and GOM}

Total gaseous mercury (TGM) was monitored from November 2009 and November 2010. The inlet of the heated Teflon sampling tubing for TGM monitoring was positioned at $10 \mathrm{~m}$ above the ground. Measurement of the TGM concentrations was performed using an automated $\mathrm{Hg}$ vapor analyzer Tekran model 2537A (Tekran Instruments Corp., Toronto, Ontario, Canada). The instrument allows continuous measurement of TGM (GEM + GOM) in ambient air through a cycle of gold trap amalgamation, thermal desorption and detection by cold vapor atomic fluorescence spectrometry $(\lambda=253.7 \mathrm{~nm})$. The precision, accuracy and stability of the instrument have been documented extensively (Gay et al., 2013b). The Tekran 2537A automatically calibrates for GEM every $25 \mathrm{~h}$ using an internal permeation source, which provides approximately $1 \mathrm{pg} \mathrm{s}^{-1}$ of GEM at $50^{\circ} \mathrm{C}$ into a zero air stream. External calibration using a Tekran 2505 with manual injections of known concentrations of GEM was performed every 4 months. The measurement accuracy based on the manual injection calibrations was $96.84 \%$. The precision was $<2 \%$ with a detection limit $<0.1 \mathrm{ng} \mathrm{m}^{-3}$. PBM in ambient air was removed using a $47 \mathrm{~mm}$ diameter Teflon filter (pore size $0.2 \mu \mathrm{m}$ ). For sampling at the reduced ambient pressure at the site, a lower sampling rate of $0.75 \mathrm{~L} \mathrm{~min}^{-1}$ (at standard temperature and pressure, as compared to the typical $1.0 \mathrm{~L} \mathrm{~min}^{-1}$ ) at sampling interval of $5 \mathrm{~min}$ was used during the entire campaign (Fu et al., 2012a) .

A denuder-based sampling unit (separate from the TGM sampling train) was used for sampling PBM and GOM. Detailed schematics of the sampling unit, instrumental configuration and field illustrations are shown in the supplementary information (Supplement Figs. S1-S5). In short, the annular denuder tubes (URG Corporation) are made of quartz with the inner wall coated with $\mathrm{KCl}$ for GOM sampling. An integrated elutriator/acceleration jet and an impactor capable of removing coarse particles $(>2.5 \mu \mathrm{m})$ were installed in front of the inlet of the denuder. The PBM and GOM samples were collected continuously and analyzed immediately. A fresh glass plate in the impactor was replaced upon completing each sampling cycle. PBM (defined as $\mathrm{Hg}$ associated with particles with a size $<2.5 \mu \mathrm{m}$ ) was collected on the $47 \mathrm{~mm}$ diameter quartz filters housed in a Teflon filter holder downstream of the denuder. The quartz filters for sampling PBM were the Whatman grade QM-H quartz filter from GE healthcare (http://www.gelifesciences.com/webapp/wcs/stores/servlet/ productById/en/GELifeSciences/28418567). This is a pure quartz fiber filter with low heavy metal content, and can be used at temperatures of up to $900^{\circ} \mathrm{C}$. Each quartz filter was used for one sampling and analysis cycle to prevent potential deformation and contamination. A KCl-coated denuder was installed in the sampling unit with an impactor. Once a sampling period was completed, another prepared PBM and GOM sampling unit was installed swiftly for the next sampling cycle. The typical replacement time of each denuder and filter was short ( $\sim 10 \mathrm{~min}$ ) (Xiao et al., 1997; Landis et al., 2002a; Feng et al., 2000). Both the PBM filter and denuder were positioned vertically. The inlets were located at $1.5 \mathrm{~m}$ above the ground. A temperature-controlled heating tape was utilized to maintain the temperature of the denuder sampling train at $40-50^{\circ} \mathrm{C}$ above the ambient temperature to prevent water condensation on the $\mathrm{KCl}$ coating and the wall loss of GOM in the sampling tube (Feng et al., 2000). The sampling flow rate $\left(10 \mathrm{~L} \mathrm{~min}^{-1}\right)$ for both GOM and PBM was controlled by mass-flow controllers (MKS, USA) calibrated to standard atmospheric pressure $\left(0^{\circ} \mathrm{C}\right.$ and 1013 mbar). Two identical units were deployed: one was used for the air sampling while the other was undergoing $\mathrm{Hg}$ desorption and detection. The GOM and PBM were sampled simultaneously and each analysis cycle was $2 \mathrm{~h}$. Using this sampling protocol, $12 \mathrm{GOM}$ and $12 \mathrm{PBM}$ samples were collected per day. The denuder and filter were analyzed immediately after air sampling.

Analytical procedures for GOM described by Munthe et al. (2001), Lynam et al. (2002) and Landis et al. (2002a) were followed. The PBM analysis was achieved using a heating method. After sampling, $\mathrm{Hg}$ contents were determined via pyrolysis followed by Tekran 2537A detection. First, the Tekran 2537A pulled $\mathrm{Hg}$-free air $\left(0.5 \mathrm{~L} \mathrm{~min}^{-1}\right)$ through the filter trap and denuders for two sample cycles $(10 \mathrm{~min})$ to confirm the zero background for ensuring no leaks in the system. The filter was placed into the trap using an installation tool (nichrome wire with a hook at one end). Then, the trap and denuders were rapidly heated to 900 and $500{ }^{\circ} \mathrm{C}$ using a Lindberg Blue clamshell furnace for three heating cycles (15 min) to convert PBM and GOM into GEM, which was then analyzed by the Tekran 2537A. To prevent the end caps of denuder and trap from emitting mercury during heating, air cooling was applied on both ends of the denuder. A signal of $<2 \mathrm{pg}$ was typically observed before the third heating cycle, indistinguishable from the system blank. The PBM traps and denuders were then cooled by a cooling fan after the third heating cycle (Figs. S4-S6).

Four sampling campaigns were carried out for PBM and GOM measurements: 17 January-1 February, 8-18 May, 1025 July and 28 October-11 November 2010 . The periods were selected to represent the four different seasons. Before sampling, the denuders were cleaned via pyrolysis to obtain the blank ( $1.67 \pm 0.66 \mathrm{pg}, N=12)$. The quartz filter was cleaned by heating at $850^{\circ} \mathrm{C}$ for $30 \mathrm{~min}$. A somewhat higher blank (6.62 $\pm 2.69 \mathrm{pg}, N=20)$ was observed. The denuder and quartz filter blanks were used for correcting the GOM 
Table 1. The seasonal statistics of the measured TGM, GOM, PBM, WS, AT, RH and RF from November 2009 through November 2010 at the SAWRS site. $N$ is the number of samples.

\begin{tabular}{|c|c|c|c|c|c|c|c|c|}
\hline & & $\begin{array}{l}\text { TGM } \\
\left(\mathrm{ng} \mathrm{m}^{-3}\right)\end{array}$ & $\begin{array}{l}\text { GOM } \\
\left(\mathrm{pg} \mathrm{m}^{-3}\right)\end{array}$ & $\begin{array}{l}\text { PBM } \\
\left(\mathrm{pg} \mathrm{m}^{-3}\right)\end{array}$ & $\begin{array}{l}\text { AT } \\
\left({ }^{\circ} \mathrm{C}\right)\end{array}$ & $\begin{array}{l}\mathrm{RH} \\
(\%)\end{array}$ & $\begin{array}{l}\text { WS } \\
\left(\mathrm{m} \mathrm{s}^{-1}\right)\end{array}$ & $\begin{array}{l}\mathrm{RF} \\
(\mathrm{mm})\end{array}$ \\
\hline Spring & Mean & 2.76 & 3.20 & 33.53 & 4.85 & 78.06 & 1.98 & 34.07 \\
\hline \multirow[t]{4}{*}{ Mar-May } & SD & 0.87 & 3.27 & 25.05 & 3.32 & 12.88 & 0.63 & \\
\hline & Median & 2.6 & 2.12 & 27.28 & 4.05 & 79.5 & 1.9 & \\
\hline & Range & $1.43-13.59$ & $0.71-16.69$ & $3.80-112.82$ & $-0.4-13$ & $37-98$ & $0.7-3.4$ & 90 \\
\hline & $\mathrm{N}$ & 18706 & 43 & 46 & 2160 & 2160 & 2160 & \\
\hline \multirow{5}{*}{$\begin{array}{l}\text { Summer } \\
\text { Jun-Aug }\end{array}$} & Mean & 2.51 & 3.96 & 26.14 & 12.37 & 85.97 & 1.63 & 183.97 \\
\hline & SD & 0.71 & 3.82 & 18.17 & 1.59 & 7.91 & 0.61 & \\
\hline & Median & 2.35 & 2.85 & 22.33 & 12.4 & 87 & 1.5 & \\
\hline & Range & $1.05-6.11$ & $0.77-18.81$ & $3.02-86.97$ & $7.2-15.6$ & 65-99 & $0.5-3.4$ & 95 \\
\hline & $\mathrm{N}$ & 17662 & 80 & 69 & 2280 & 2280 & 2280 & \\
\hline \multirow{5}{*}{$\begin{array}{l}\text { Autumn } \\
\text { Sep-Nov }\end{array}$} & Mean & 2.71 & 7.60 & 57.63 & 6.25 & 84.46 & 1.5 & 38.17 \\
\hline & SD & 0.79 & 6.15 & 36.49 & 3.61 & 8.39 & 0.44 & \\
\hline & Median & 2.59 & 5.27 & 45.82 & 6.3 & 84.5 & 1.5 & \\
\hline & Range & $1.03-6.99$ & $0.78-31.09$ & $10.93-185.06$ & $-0.3-11.7$ & $63-99$ & $0.4-2.66$ & 95 \\
\hline & $\mathrm{N}$ & 13161 & 103 & 100 & 2280 & 2280 & 2280 & \\
\hline \multirow{5}{*}{$\begin{array}{l}\text { Winter } \\
\text { Dec-Feb }\end{array}$} & Mean & 2.28 & 14.62 & 21.36 & -1.37 & 54.68 & 2.34 & 0 \\
\hline & SD & 0.42 & 9.12 & 15.72 & 1.64 & 16.98 & 0.72 & \\
\hline & Median & 2.22 & 13.09 & 15.23 & -1.11 & 58 & 2.25 & \\
\hline & Range & $1.18-4.51$ & $2.70-39.85$ & $3.76-65.9$ & $-6.6-1.6$ & $19-84$ & $0.9-4.3$ & 94 \\
\hline & $\mathrm{N}$ & 20003 & 97 & 53 & 2256 & 2256 & 2256 & \\
\hline \multirow[t]{5}{*}{ Total } & Mean & 2.55 & 8.22 & 38.32 & 5.57 & 75.97 & 1.86 & \\
\hline & SD & 0.73 & 7.90 & 31.26 & 5.57 & 16.81 & 0.68 & \\
\hline & Median & 2.39 & 5.16 & 30.67 & 5.1 & 79 & 1.8 & \\
\hline & Range & $1.03-13.59$ & $0.71-39.85$ & $3.02-185.59$ & $-6.6-15.6$ & 19-99 & $0.4-4.3$ & 374 \\
\hline & $\mathrm{N}$ & 69532 & 323 & 268 & 8976 & 8976 & 8976 & \\
\hline
\end{tabular}

and PBM concentrations by subtracting the mean blank from the detected concentration. This GMOS standard operational procedure was followed to ensure data quality. For quality assurance, the A/B cartridge bias of the Tekran 2537A must be $<10 \%$. Using the data quality assurance criteria of GMOS, the data completeness in this study was $92.6 \%$ of the total sample size.

\subsection{Meteorological data and back-trajectory calculation}

Meteorological parameters including hourly wind direction (WD), wind speed (WS), air temperature (AT), relative humidity (RH) and rainfall (RF) were continuously monitored using an automatic weather station (PH-SLFH, China) at SAWRS. The Indian monsoon indices (IMI), defined as the difference of $850 \mathrm{hPa}$ zonal winds between a southern region $\left(5-15^{\circ} \mathrm{N}, 40-80^{\circ} \mathrm{E}\right)$ and a north- ern region $\left(20-30^{\circ} \mathrm{N}, 7-90^{\circ} \mathrm{E}\right)$ (Wang and Fan, 1999; Wang et al., 2001), were obtained online at the AsiaPacific Air Data-Research Center (http://apdrc.soest.hawaii. edu/projects/monsoon/realtime-monidx.html). The IMI reflects both the intensity of the tropical westerly monsoon and the lower-tropospheric vorticity anomalies associated with the ISM trough. With a positive IMI, the study site was expected to be influenced by air transport caused by the ISM, characterized by wet air flow from the Indian Ocean and high rainfall. A zero IMI indicates weak air movement. A negative IMI indicates that northerly winds push the air mass back the Indian Ocean. Five-day back trajectories were calculated using HYSPLIT4 (Wang et al., 2009) to assess the transport pathways (http://www.arl.noaa.gov/ready/hysplit4. html). The Global Data Assimilation System (GDAS) meteorology archived by the Air Resource Laboratory of National Oceanic and Atmospheric Administration (NOAA) was used 
as the input (ftp://arlftp.arlhq.noaa.gov/pub/archives/gdas1/). The spatial and temporal resolution of the met data is $1^{\circ} \times 1^{\circ}$ and $6 \mathrm{~h}$, respectively. The arrival height of the trajectories was set at $500 \mathrm{~m}$ above the ground. The back-trajectory endpoints were recorded at $6 \mathrm{~h}$ intervals $(02: 00,08: 00,14: 00$ and 20:00 LT).

Cluster analysis of the back trajectories was performed to obtain the synoptic transport pattern to the site. Clustering was initiated by assigning each trajectory to its own cluster, so that there were the same number of clusters as the number of trajectories (i.e., one trajectory in each cluster). For each iteration step, the cluster number was reduced by one as two clusters were merged together. For every combination of trajectory pairs, the cluster spatial variance (SV), defined as the sum of the squared distances between the endpoints of the cluster's component trajectories and the mean of the trajectories in that cluster, was computed. Then the total spatial variance (TSV), defined as the sum of all cluster SV and increased for each additional inclusion of a trajectory, was calculated. The clustering process continued until the TSV suddenly increased by a large value, indicating that the included trajectory in the given iteration was not similar to the included trajectories in a cluster. Such processes continued until the iterative step just before the large increase in the change in TSV gave the final number of clusters. Once the number of clusters was determined, the endpoints of trajectories in the same cluster were averaged and shown on the map (Wang et al., 2009; Dorling et al., 1992). A similar analysis has been used in previous studies (Rozwadowska et al., 2010; Landis et al., 2002b; Fu et al., 2012a).

A potential source contribution function (PSCF) was performed to analyze and estimate the influence of the potential sources. The PSCF value for the $i j$ th cell is then defined as

$\operatorname{PSCF}_{i j}=\frac{M_{i j}}{N_{i j}}$,

where $M_{i j}$ represents the number of trajectory endpoints associated with 85 or higher percentiles of the observed TGM and $N_{i j}$ is the number of endpoints associated with 50 or higher percentiles of the observed TGM. To reduce the effect of small values of $N_{i j}$, the PSCF values were multiplied by a weight function $W_{i j}$ to reflect the uncertainty of the values in these cells (Polissar et al., 2001). The endpoints reaching the ground were excluded in the PSCF calculation. Overall, more than 27000 endpoints were included for the calculation. The weighting function was defined as

$W_{i j}= \begin{cases}1.0 & n_{i j}>3 \mathrm{Avg} \\ 0.7 & 1.5 \mathrm{Avg}<n_{i j} \leq 3 \mathrm{Avg} \\ 0.4 & \operatorname{Avg}<n_{i j} \leq 1.5 \mathrm{Avg} \\ 0.2 & n_{i j} \leq \mathrm{Avg},\end{cases}$

where Avg is the average endpoints in each grid cells.

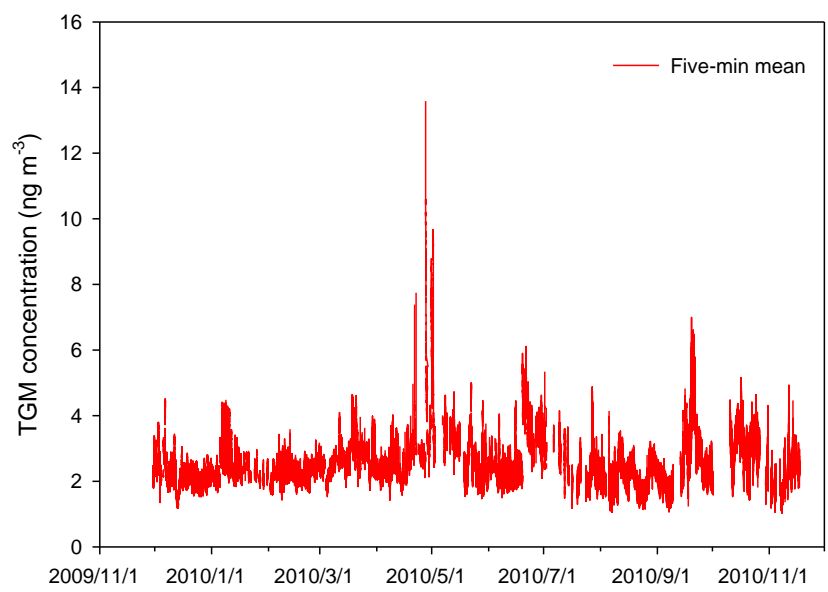

Figure 2. The 5-min time series distribution of TGM concentrations at SAWRS in the campaign. Spikes of high TGM concentrations were observed from late April through early May, from late June through early July and in late September.

\section{Results and discussion}

\subsection{Distribution and influences of potential regional sources}

The 5-min time series plot of the TGM concentrations is shown in Fig. 2. The concentrations ranged from 1.03 to $13.59 \mathrm{ng} \mathrm{m}^{-3}$ with a mean of $2.55 \pm 0.73 \mathrm{ng} \mathrm{m}^{-3}$ (Table 1). Spikes of high TGM concentrations were observed from late April through early May $\left(5.87 \mathrm{ng} \mathrm{m}^{-3}\right)$, from late June through early July $\left(4.58 \mathrm{ng} \mathrm{m}^{-3}\right)$, and in late September $\left(4.74 \mathrm{ng} \mathrm{m}^{-3}\right)$. The three high-TGM events occurred during the months when the ISM was prevailing (further discussed in Sect. 3.3). The levels of TGM at SAWRS were much lower than those observed in southwestern Chinese cities $\left(9.7 \pm 10.2 \mathrm{ng} \mathrm{m}^{-3}\right.$ in Guiyang (Fu et al., 2011), $6.74 \pm 0.37 \mathrm{ng} \mathrm{m}^{-3}$ in Chongqing (Yang et al., 2009)), the background concentrations observed at Mt. Leigong in Guizhou province $\left(2.80 \pm 1.51 \mathrm{ng} \mathrm{m}^{-3}\right.$; Fu et al., 2010), and Mt. Gongga in Sichuan province $\left(3.98 \pm 1.62 \mathrm{ng} \mathrm{m}^{-3}\right.$; $\mathrm{Fu}$ et al., 2008). However, they are higher than those observed at Mt. Changbai $\left(1.60 \pm 0.51 \mathrm{ng} \mathrm{m}^{-3}\right)$ in northeastern China, and at Mt. Waliguan (WLG) Baseline Observatory $\left(1.98 \pm 0.98 \mathrm{ng} \mathrm{m}^{-3}\right)$ in Tibetan Plateau (Fu et al., 2012a; Fu et. al, 2012b).

SAWRS is located between East Asia and South Asia, where large $\mathrm{Hg}$ emission sources exist (Fig. 1). The TGM concentrations measured at Korean and Japanese background sites were also much higher due to the nearby emission sources and the prevailing westerly winds $\left(4.61 \mathrm{ng} \mathrm{m}^{-3}\right.$ at the Global Atmospheric Watch Station on An-Myun Island of Korea (Nguyen et al., 2007) and $2.04 \mathrm{ng} \mathrm{m}^{-3}$ at Cape Hedo Station on Okinawa Island of Japan (Jaffe et al., 2005)). The GEM level of Lulin Atmospheric Background Station in 


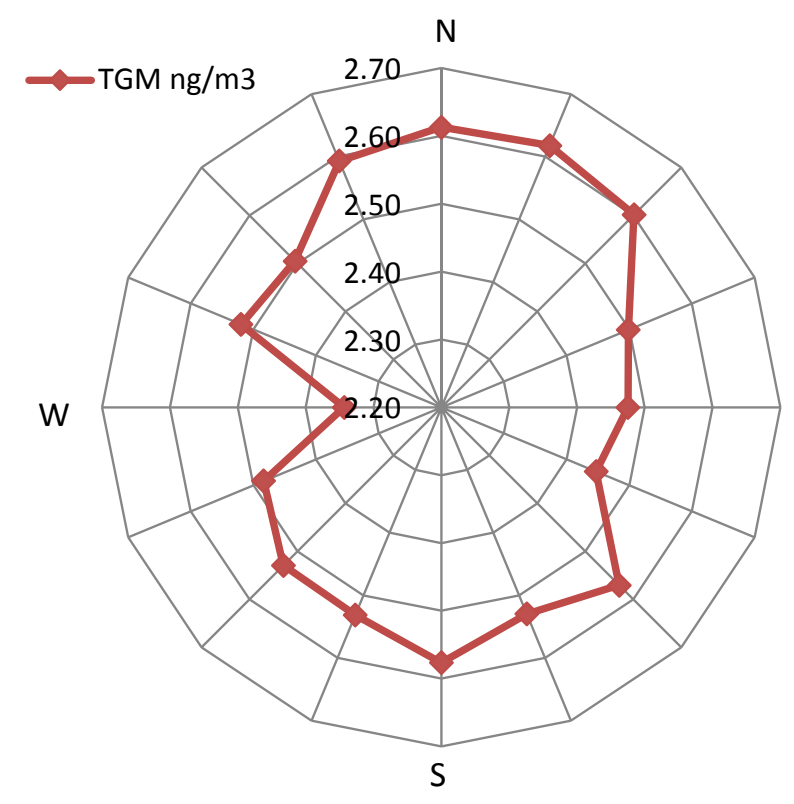

Figure 3. Concentration wind rose for SAWRS. TGM concentration exhibited a strong dependence on wind direction. Higher TGM levels were frequently associated with northerly winds.

Taiwan $\left(1.73 \mathrm{ng} \mathrm{m}^{-3}\right)$ was comparatively lower. The mean TGM concentration at SAWRS was higher than those measured at background sites in North America and Europe $\left(1.5 \mathrm{ng} \mathrm{m}^{-3}\right.$ from the North America Atmospheric Mercury Network, $1.4-1.8 \mathrm{ng} \mathrm{m}^{-3}$ at Mace Head and Zingst in Europe; Kock et al., 2005; Gay et al., 2013b). The elevated background level of TGM at SAWRS is likely due to strong regional sources in Asia. It can also be influenced by longrange transport (Obrist et al., 2008; Fu et al., 2012a) and occasionally by the weak local sources.

The measured TGM concentration exhibited a strong dependence on wind direction. Higher TGM levels (2.5$2.7 \mathrm{ng} \mathrm{m}^{-3}$ ) were frequently associated with northerly winds that carried domestic emissions from western China to the site (Fig. 3). The elevated TGM concentrations (2.5$2.6 \mathrm{ng} \mathrm{m}^{-3}$ ) associated with the southerly winds could be caused by a combination of the regional emission sources in South Asia and occasional local emissions in Shangri-La County. The wind flows from the east and west contained lower TGM concentrations $\left(2.3-2.5 \mathrm{ng} \mathrm{m}^{-3}\right)$. The mountain ranges in the Shangri-La area run in the north-south direction. The air masses in the east-west direction needed to cross high mountains and passed over fewer known source regions before reaching SAWRS.

Figure 4 displays the averaged diurnal trend of WD and WS along with those of TGM, GOM and PBM. The WD was predominantly southerly and changed from southeast (daytime) to southwest (nighttime). WS and TGM were slightly higher during daytime. Since SAWRS is located on a small mountaintop in Hengduan Mountains area, the terrain can af-

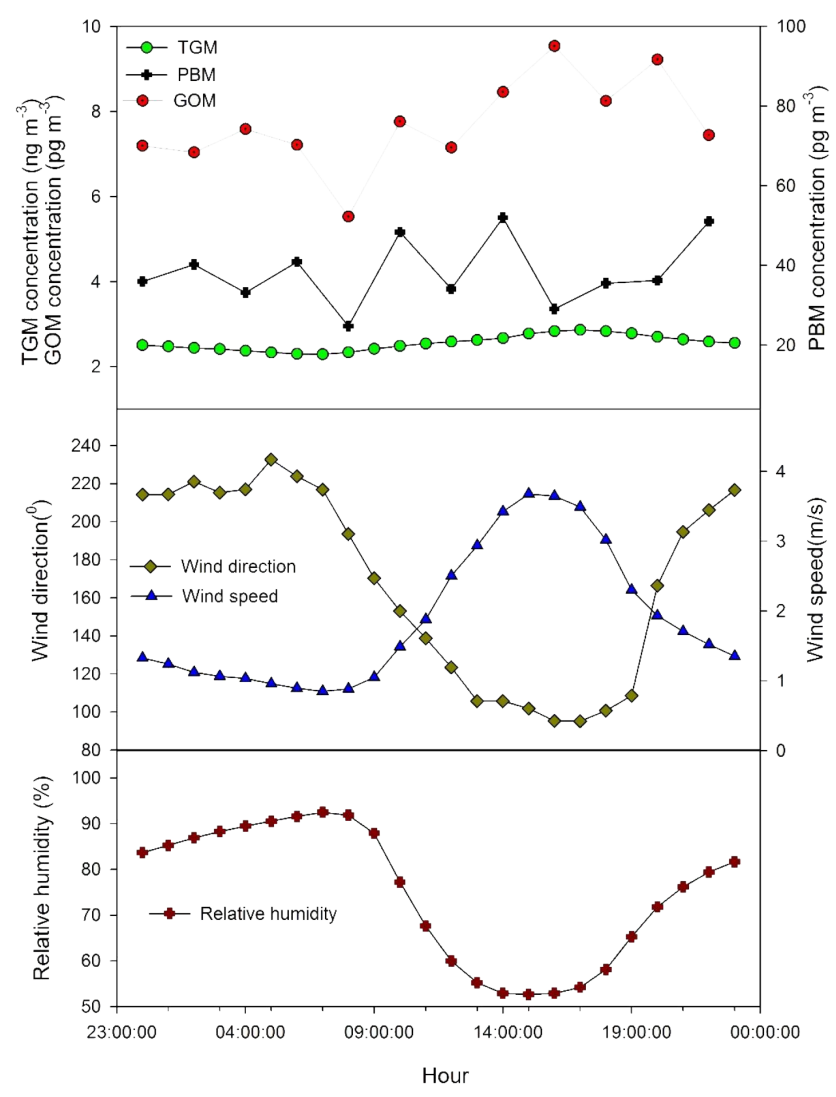

Figure 4. The diurnal variation in TGM, GOM and PBM with WD, WS and RH.

fect local air circulation. It was possible that diurnal mountain valley breezes played a role in the vertical mixing and contributed to the observed diurnal variation. During daytime, air near the valley was heatsed up faster than the air at the high altitude. The air mass rapidly rose and brought the $\mathrm{Hg}$ trapped in the boundary layer to the monitoring site. At nighttime, the cool air from the high mountains sank and carried the clean air from higher altitude to the site (Fu et al., 2010).

The diurnal pattern of GOM at SAWRS showed higher concentrations in the afternoon. The relative humidity in the afternoon (14:00-20:00) was 58.24\%, much lower than the $81.47 \%$ at night and in the morning (21:00-13:00). The mean GOM concentration in the afternoon was $9.22 \mathrm{pg} \mathrm{m}^{-3}$. This was higher than the $7.34 \mathrm{pg} \mathrm{m}^{-3}$ observed during evening through morning hours. A possible reason was the lower relative humidity during the afternoon hours decreased the scavenging of GOM into atmospheric water. Another explanation was the oxidation of $\mathrm{Hg}^{0}$ caused by the stronger solar radiation (Lindberg et al., 2002; Goodsite et al., 2004; Faïn et al., 2009). The measured PBM did not show a distinct diurnal trend. The observed diurnal pattern of TGM and GOM reflected the influence of local meteorology and photochemical production. 


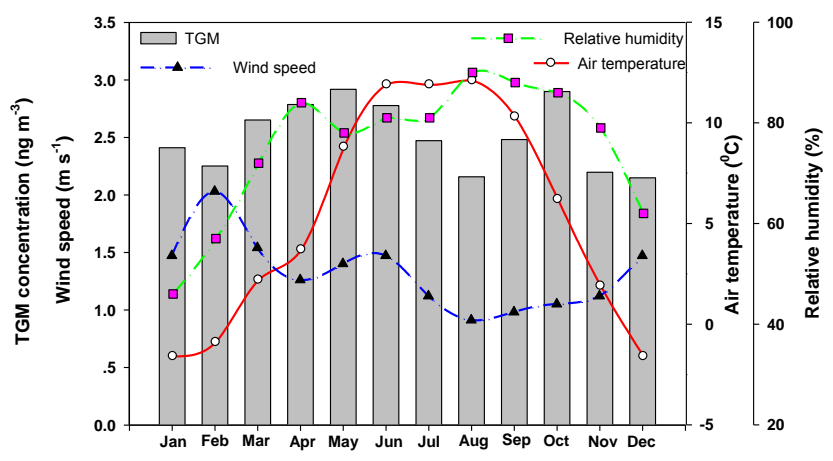

Figure 5. The variation in the monthly means of TGM, WS, AT and RH. TGM concentration is high in the ISM period with high AT and RH.

\subsection{Seasonal patterns of TGM, GOM and PBM}

The seasonal statistics of the measured TGM, GOM, PBM, WS, AT, RH and RF are shown in Table 1. The mean TGM concentration in winter was the lowest $\left(2.28 \mathrm{ng} \mathrm{m}^{-3}\right)$ among the four seasons. In addition, temperature, RH and RF were lower in winter after the retreat of the ISM. During the period, dry air masses, typically associated with high WS, from the Tibetan Plateau caused the lower observed TGM. The TGM level was highest in spring $\left(2.76 \mathrm{ng} \mathrm{m}^{-3}\right)$ and peaked in late April (Fig. 2), when RF, AT and RH increased with the onset of the ISM. Statistical analysis indicated that the TGM concentrations in spring were statistically higher than the levels in autumn $(P<0.001)$ and winter $(P=0.004)$ (Table S1). The high-TGM events were caused by the regional transport from the heavily industrial regions in northwestern China (more details in Sect. 3.3), with an observed peak concentration of $13.59 \mathrm{ng} \mathrm{m}^{-3}$. Elevated TGM concentrations (mean $=2.71 \mathrm{ng} \mathrm{m}^{-3}$ ) were also observed in autumn (Fig. 2), mainly associated with lower AT, RH and RF. During the ISM period, the mean TGM level was $2.51 \mathrm{ng} \mathrm{m}^{-3}$ and associated with higher RH and RF.

The variation in the monthly means of TGM, WS, AT and RH is shown in Fig. 5. During the ISM season (May to September), a negative correlation between mean TGM concentration and the RH was evident $(r=-0.83, P<0.001)$. One likely reason was that the clean air masses and water vapor from the Indian Ocean moved inland and led to high RH and low TGM. In addition, the cumulus process could also cause dilution of $\mathrm{Hg}$ in the atmosphere during precipitation events. High RH can decrease the $\mathrm{Hg}$ emission from the surface and enhance wet deposition of $\mathrm{Hg}$. Both could result in a lower TGM concentration (Seo et al., 2012; Poissant and Casimir, 1998). The TGM concentrations in late autumn and winter months were relatively lower than those in other months (except August), likely due to the high WS and dry air masses from the Tibetan Plateau associated with the strengthening of Westerlies. The variability in WS in autumn
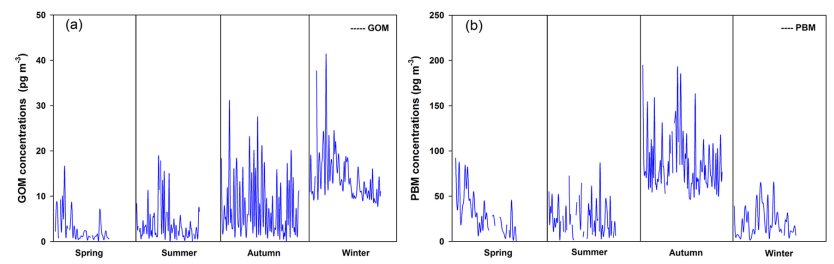

Figure 6. Seasonal variability in GOM and PBM during four sampling campaigns.

and winter could not explain the observed seasonal variation in TGM level in the two seasons.

Both GOM (Fig. 6a) and PBM (Fig. 6b) exhibited substantial seasonal variability. GOM concentrations in winter were significantly higher than the levels in the other seasons $(P<0.001)$ (Table S2). The GOM concentrations were higher in autumn (mean $=7.60 \mathrm{pg} \mathrm{m}^{-3}$ ) and peaked in winter (14.62 $\mathrm{pg} \mathrm{m}^{-3}$, about 4 times that of the mean level in spring, $3.20 \mathrm{pg} \mathrm{m}^{-3}$ ). A similar pattern was observed at Storm Peak Laboratory ( 3220 ma.s.l.) in the Rocky Mountains in the USA Faïn et al., 2009). In the cold season, the air mass arriving in Shangri-La was primarily carried by the Westerlies with relatively higher wind speed (mean $=2.34 \mathrm{~m} \mathrm{~s}^{-1}$ in winter). These air masses occasionally passed through strong source regions in South and Southeast Asia as well as local anthropogenic sources from domestic biofuel burning for house heating, and therefore potentially transported $\mathrm{Hg}$ to the site. The slightly higher GOM could be caused by local photochemical transformation under low RH (54.7\%).

The PBM concentrations were the highest in autumn, with a peak concentration of $57.63 \mathrm{pg} \mathrm{m}^{-3}$. This is significantly higher than the concentrations in summer $(P<0.05)$ and in winter $(P<0.001)$ (Table S3). In the absence of volcanic sources, PBM concentrations are usually associated with $\mathrm{Hg}$ emission from anthropogenic activities (Friedli et al., 2003; Finley et al., 2009). There are several small villages in the Shangri-La area. Due to the high elevation $(3850 \mathrm{~m}$ above sea level), the weather was already cold in autumn. For house heating, domestic biofuel burning from local anthropogenic sources could have contributed to the high PBM level at SAWRS. Back-trajectory analysis suggested that high PBM events in other seasons were associated with the air mass from Myanmar, Vietnam, Laos, Cambodia and Thailand. Previous studies showed that the emission from the region could cause elevated TGM concentrations measured at a remote site (Sheu et al., 2013). Given the frequent air flows from the Southeast Asia to southwestern China, similar transport events could have taken place. The GOM and PBM levels were relatively lower from late spring to summer during the ISM period, likely due to the higher RF and RH (Table $1)$. 


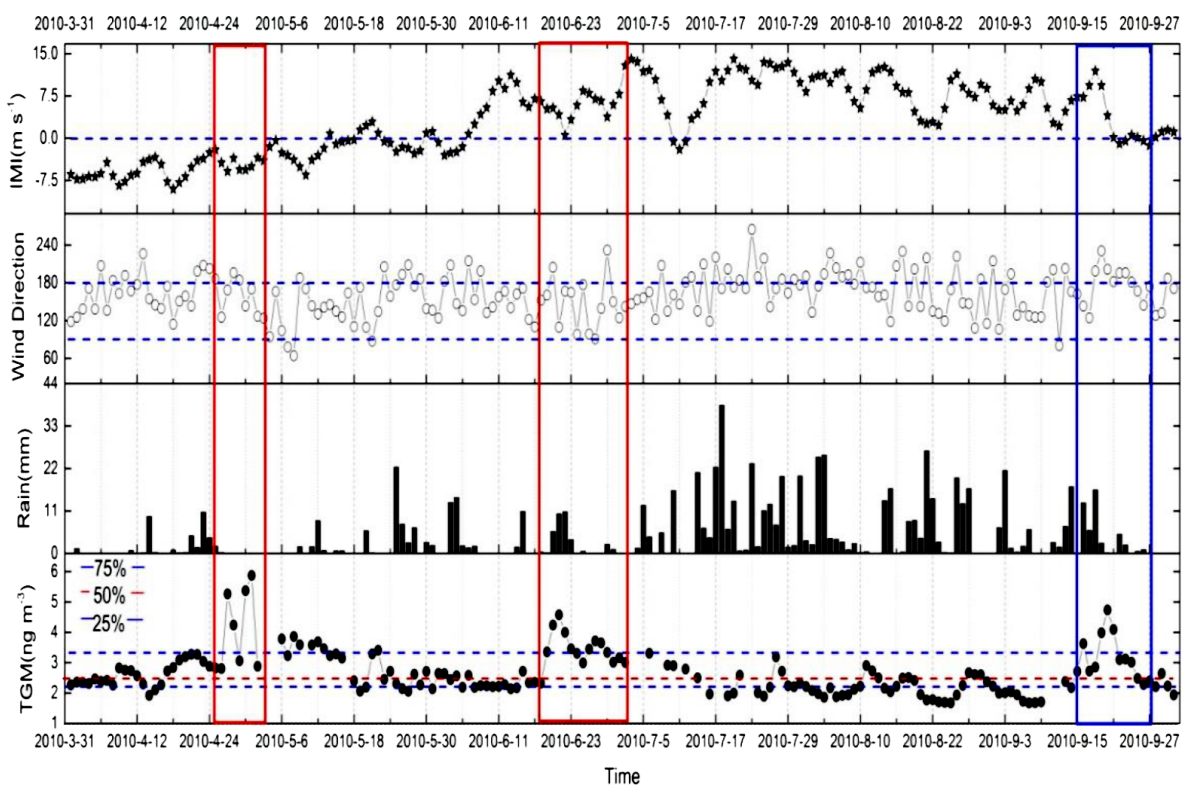

Figure 7. Time series of WD, RF and TGM and the calculated Indian monsoon index (IMI) from April to September 2010. An IMI value $>0$ indicates air movement from south toward north, which is also associated with greater precipitation. WD measured at SAWRS was mostly from the southeast. Zero IMI indicates weak air movement. Negative IMI indicates northerly wind that pushes the air back to the Indian Ocean. Areas highlighted in red show times when the causes of these events are impacted not only by local airflow but also long-term transportation, while the blue area just represents the local airflow impact.

\subsection{Air mass back-trajectories analysis}

Figure 7 shows the time series of WD, RF and TGM with the calculated Indian monsoon index (IMI) during the ISM months (April through September). The IMI values represent seasonal rainfall anomalies, and are highly correlated with the transport mediated by the ISM (Wang et al., 2001). An IMI value of $>0$ suggests air transport from South Asia. Such a transport pattern was consistent from late May through mid-September. During the ISM period, WD was mainly from the southeast with relatively low wind speeds (mean $=1.63 \mathrm{~m} \mathrm{~s}^{-1}$ in summer) and high precipitations. Although the mean TGM level in ISM period was relatively higher, the high-TGM events did not persist throughout the entire ISM season. This suggested that the cumulus process and high RH could cause the low TGM level during ISM period.

The three high-TGM events shown in Fig. 7 were further analyzed. Figure 8 shows the back trajectories during 26 April to 2 May (first block in Fig. 7). The air masses originated from Siberia moved over northern Xinjiang, eastern Qinghai, Gansu and western Sichuan provinces. These are the industrial areas in northwestern China that have major $\mathrm{Hg}$ emission sources (Fig. 1) from the use of fossil fuels (Wang et al., 2000; Fu et al., 2008; Fu et al., 2012a; Fu et al., 2012c). From June 19 to July 2 (second block in Fig. 7), the air mass was mainly from the Bengal and Myanmar because of the ISM (Fig. 9), suggesting transboundary trans-

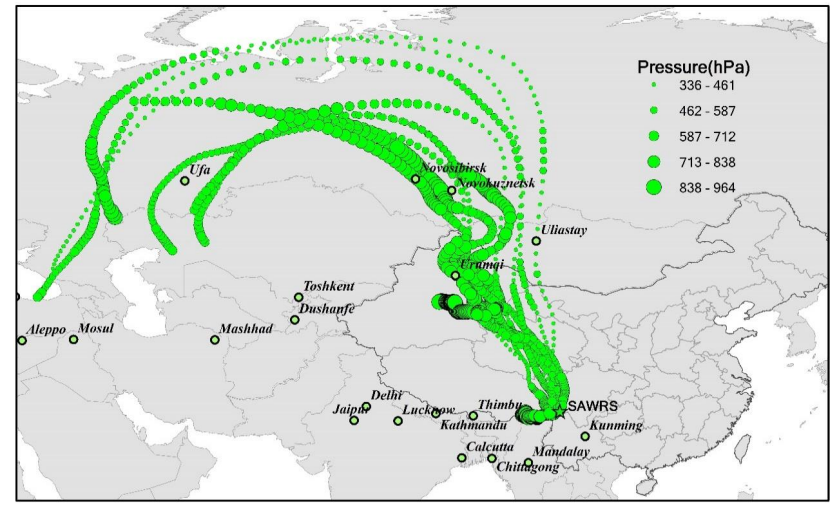

Figure 8. The back trajectories of air masses from 26 April to 2 May. High pressure means that the trajectory heights are low, and therefore the air masses can easily transport mercury emitted from the surface to SAWRS.

port caused by the anthropogenic sources in industrial cities (Fig. 1) such as Yangon (Myanmar's capital) and Bangkok (Thailand's capital). Fig. 10 shows the back trajectories during 17-22 September (third block in Fig. 7). Most trajectories in this period were short and reached the ground (the endpoints were not shown after grounding). The elevated concentration in this event could be contributed by the nearby domestic emissions. 




Figure 9. The back trajectories of air mass from 19 June to 2 July.

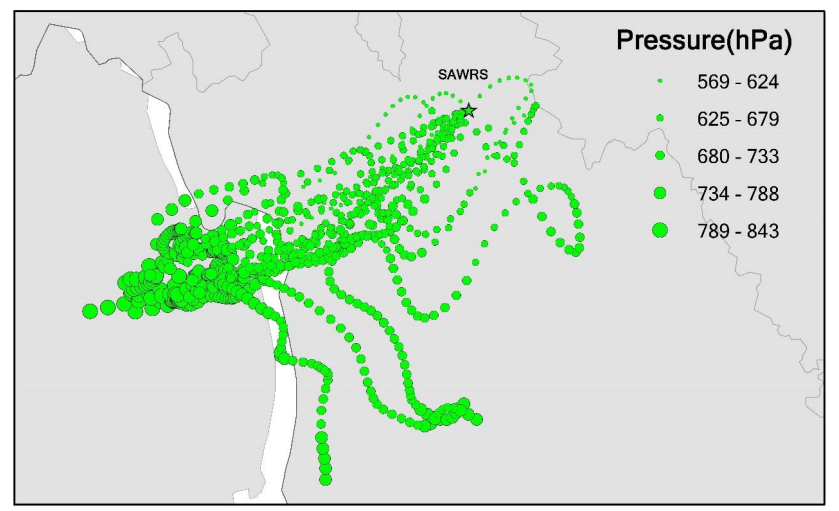

Figure 10. The back trajectories of air mass from 17 to 22 September. The trajectory points reaching ground level are not shown in the figure.

\subsection{Cluster analysis of back trajectories}

The back trajectories arriving at SAWRS over the study period were grouped into four clusters (Fig. 11) to show the synoptic air transport patterns, to understand the regional transport pathways, and to facilitate the identification of potential Hg source regions. Cluster 1 (19\%) represents air masses originating from North Africa and has the highest trajectory elevation (Fig. 12). The air masses passed quickly through central Asia and then over Xinjiang and Qinghai provinces and the Tibet region of China. Cluster $2(18 \%)$ and cluster $3(59 \%)$ represent the air masses originating from South Asia and northern India. The mean TGM concentration in cluster 4 was significantly higher than the mean concentrations associated with the other three clusters (Table S4). Cluster 4, although relatively infrequent (4\%), was associated with the highest TGM concentrations $\left(\right.$ mean $=3.9 \mathrm{ng} \mathrm{m}^{-3}$ ) due to air transport over known source regions in Sichuan province. The area has a high background TGM level caused by industrial and domestic coal combustion, smelting industries, cement production and biomass burning (Fu et al., 2008). Air masses of cluster 3, the most

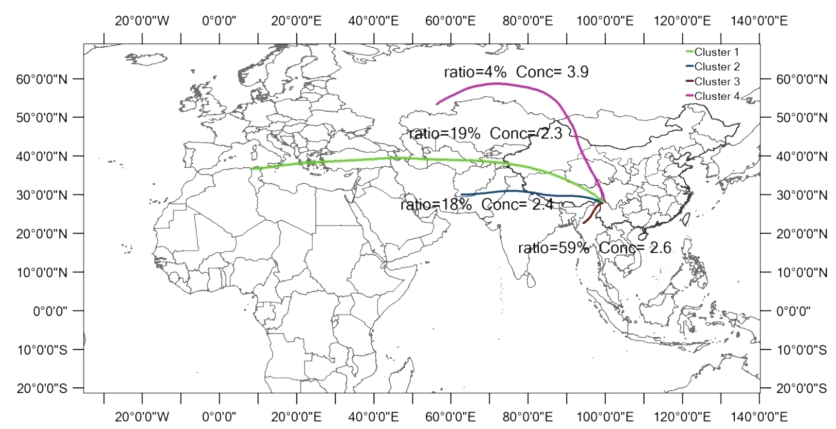

Figure 11. The back trajectories arriving at SAWRS over the study period were grouped into four clusters. Most of the air masses originated from Southeast Asia (cluster 3, $59 \%$ ), considerable air masses originated from North Africa and South Asia (cluster 1, 19\%; cluster $2,18 \%$ ), only $4 \%$ of air masses originated from central Asia and Russia.

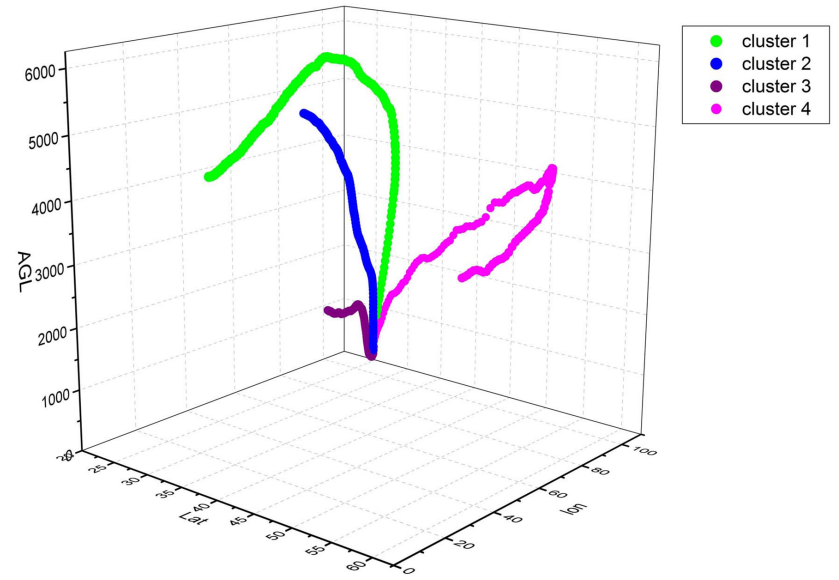

Figure 12. The three-dimensional height of all the clusters from different direction at SAWRS.

frequent transport sector, also had high TGM concentrations $\left(\right.$ mean $\left.=2.6 \mathrm{ng} \mathrm{m}^{-3}\right)$. Cluster 3 had the shortest trajectories that moved across Southeast Asian region, where extensive biomass burning occurred during early spring. The trajectory endpoints of cluster 3 had relatively lower altitude (Fig. 12) and coincided with the fire hotspots observed by MODIS (Fig. S6). This suggested that the emissions from the biomass burning can be transported to SAWRS. TGM concentration $\left(2.4 \mathrm{ng} \mathrm{m}^{-3}\right)$ associated with cluster 2, also frequent, could be linked to the transport of atmospheric $\mathrm{Hg}$ from Pakistan and northern India including New Delhi. Anthropogenic $\mathrm{Hg}$ emission in India has drawn increasing attention in recent years (Qureshi et al., 2013). Air masses in cluster 1 exhibited the lowest mean TGM concentration $\left(2.3 \mathrm{ng} \mathrm{m}^{-3}\right)$ and originated from central Asia. This cluster was also associated with high wind speed caused by the strong prevailing Westerlies in cold season. 

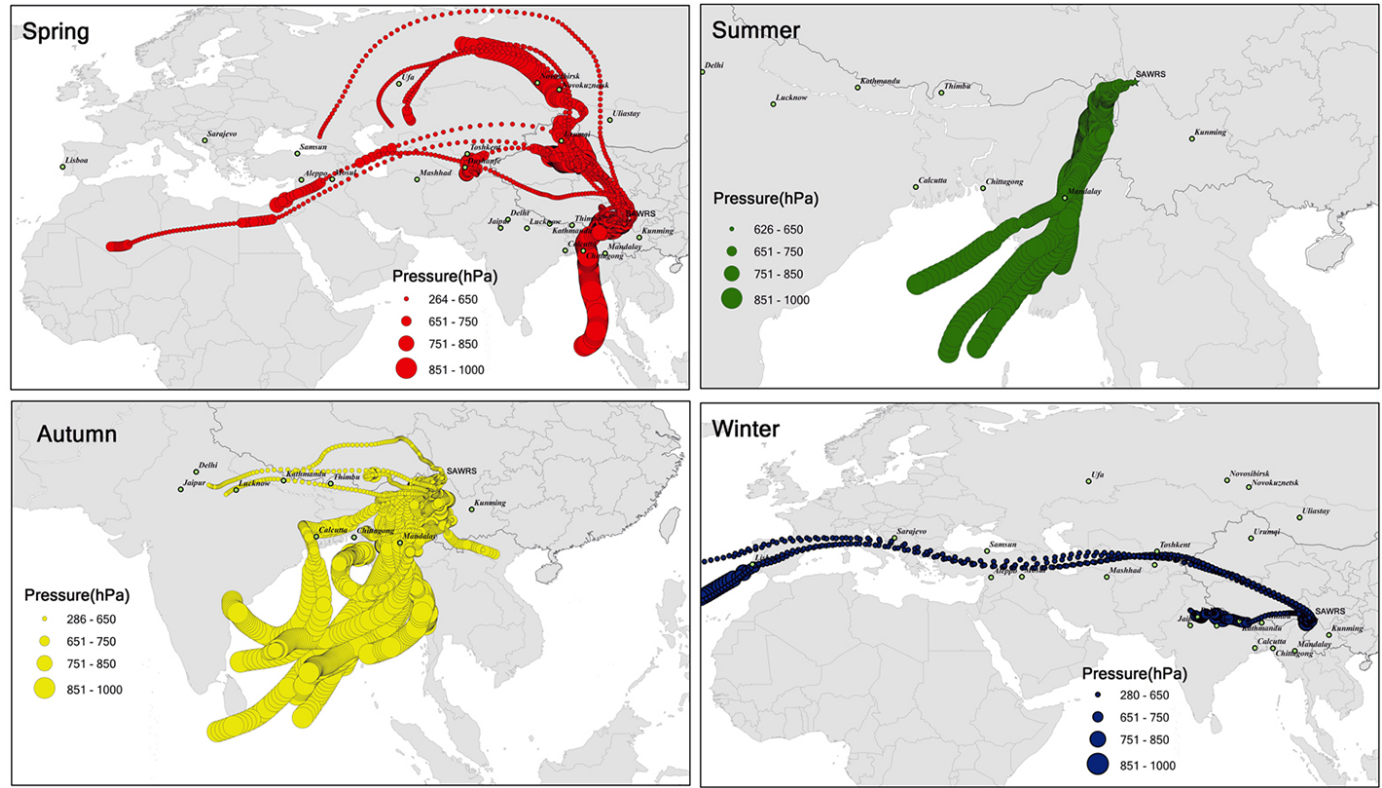

Figure 13. The back trajectories of the upper quartile of TGM observations at SAWRS for the four seasons. The air masses with high Hg were from South and Southeast Asia in summer and autumn, while some air masses with high $\mathrm{Hg}$ were from northwestern China. The rest of the air masses were from western Asia, central Asia and the Tibetan Plateau in spring and winter.
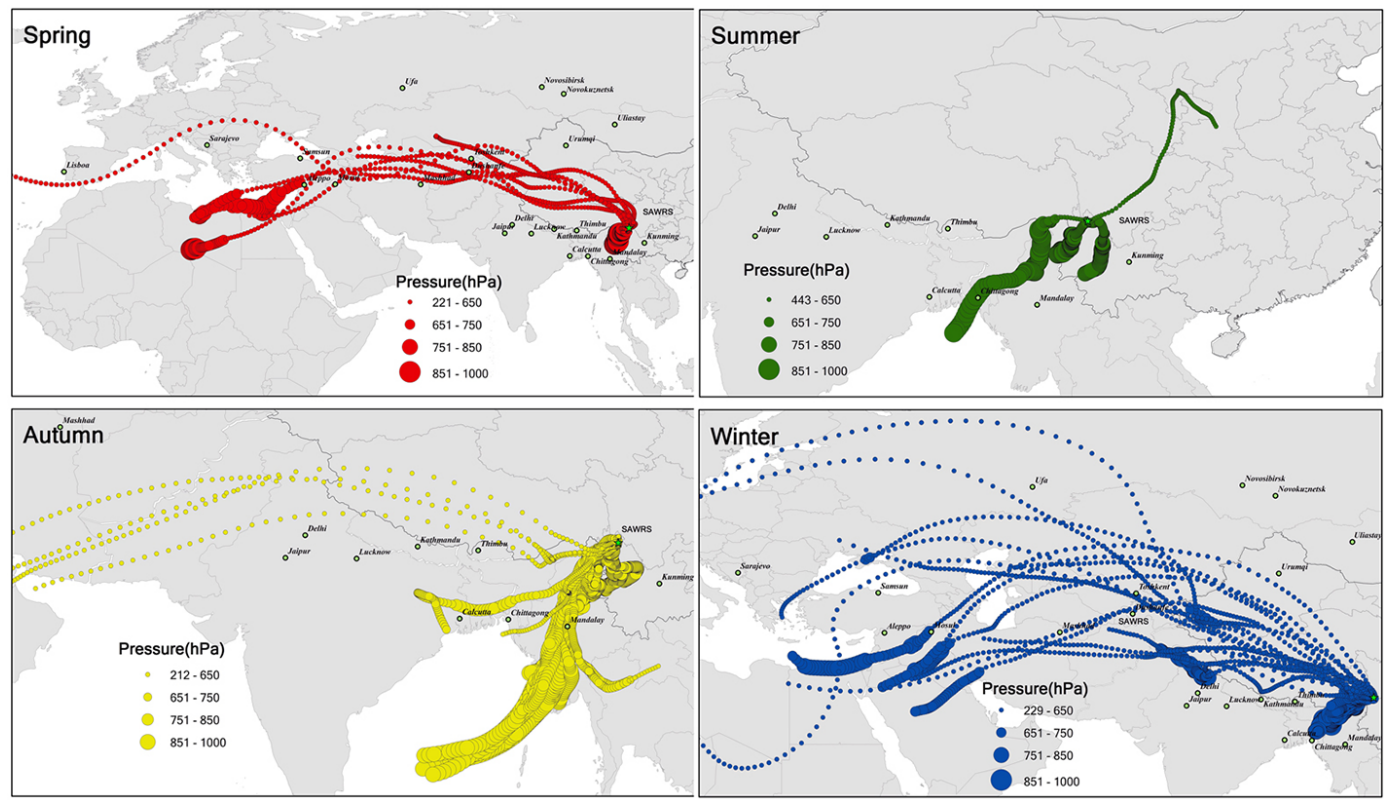

Figure 14. The back trajectories associated with the lower quartile of TGM observations in the four seasons. The air masses with low Hg from South and Southeast Asia in autumn and summer. The rest of the air masses were from western Asia, central Asia and the Tibetan Plateau.

The back trajectories of the upper quartile of TGM observations at SAWRS are displayed in Fig. 13. It is clear that the frequent transport from South and Southeast Asia during summer and autumn dominated the observed high TGM concentrations at SAWRS. The high TGM levels associated with winter trajectories originated mainly from central Asia,
North Africa and the Mediterranean and then passed through the Middle East and the Tibetan Plateau, while the highTGM events in spring were more likely caused by the domestic sources in China. The relatively shorter trajectories from South Asia suggest that the transport from this sector may be related to the slower air movement of the ISM (sum- 


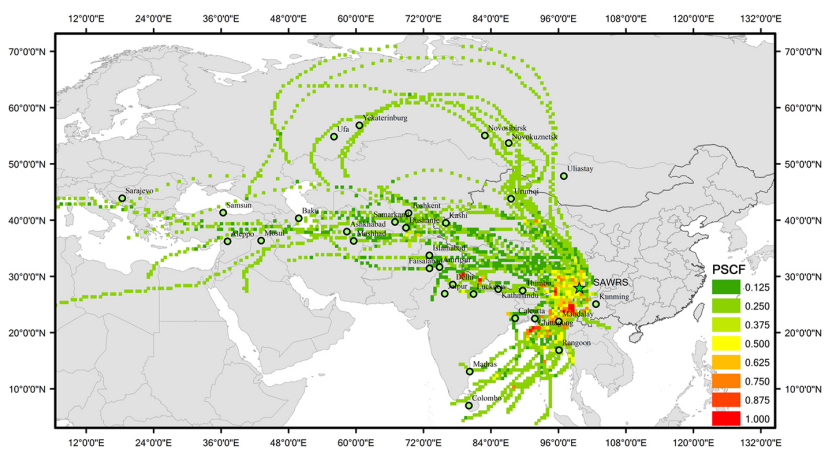

Figure 15. The potential sources and transport pathways of TGM at SAWRS identified by the PSCF. Myanmar, the Bay of Bengal, northern India, western Sichuan province and western Yunnan province were likely the potential source regions for Shangri-La.

mer and early autumn). For the lower quartile of TGM observations, most back trajectories show the same directions as the upper quartile of TGM observations (Fig. 14). However, back-trajectory endpoints associated with the lower quartile of TGM observations were comparatively higher and longer. These indicated that the air masses were traveling well above the planetary boundary layer, where ground-based emissions may not be incorporated in the air masses during the lowTGM period.

The potential sources and transport pathways of TGM at SAWRS are shown in Fig. 15. Myanmar, the Bay of Bengal, northern India, western Sichuan province and western Yunnan province were the likely source regions. Transboundary transport of aerosols released from forest fires and agricultural burning in the Bay of Bengal region has been attributed to the seasonal changes in air movement caused by monsoons (Reid et al., 2013). The PSCF analysis supported such transboundary transport events. Two high PSCF values in India were also identified, including the surrounding areas of New Delhi and Uttar Pradesh. Both are large urban areas with intensive industrial activities. Domestic source regions in Sichuan and Yunnan were also identified. The atmospheric mercury concentrations observed at SAWRS were influenced by both domestic and foreign emission sources and highly dependent on the seasonal winds that carry the air masses from different source regions to the observational site.

\section{Conclusions}

Measurements of TGM at a high-elevation background site in the southeastern corner of the Tibetan Plateau from November 2009 to November 2010 show that the mean TGM $\left(2.55 \mathrm{ng} \mathrm{m}^{-3}\right)$ was higher than typical background levels observed in the Northern Hemisphere $\left(1.5-1.7 \mathrm{ng} \mathrm{m}^{-3}\right)$. Significant seasonal variability in TGM concentration due to meteorological factors and long-range transport influenced by the ISM and Westerlies was also observed. The ISM increased the TGM levels occasionally by carrying TGMenriched air from South Asia, while moist air from the ISM decreased GOM and PBM levels. The Westerlies could carry the $\mathrm{Hg}$ emissions from the domestic sources in China to the site when the air masses moved over those source regions. The TGM concentration was higher during daytime, possibly caused by the diurnal mountain valley breezes that carried $\mathrm{Hg}$ emissions from local sources to the observation site in the afternoon hours. High GOM levels were highly correlated with dry air in autumn and winter, and in situ photochemical production might have contributed to occasionally high GOM concentration. Cluster analysis of back trajectories suggested that Southeast Asia, India and mainland China are the most important source regions for the atmospheric $\mathrm{Hg}$ at this site.

\section{The Supplement related to this article is available online at doi:10.5194/acp-15-653-2015-supplement.}

Acknowledgements. This work is supported by the National "973" Program (2013CB430003) and the Natural Science Foundation of China (41273145, 41003051). We also thank the staff of the Meteorological Bureau of Diqing Tibetan Autonomous Prefecture for field sampling assistance.

Edited by: L. Zhang

\section{References}

AMAP/UNEP: Technical Background Report for the Global Mercury Assessment 2013, in: Arctic Monitoring and Assessment Programme, Oslo, Norway/UNEP Chemicals Branch Geneva, Switzerland, 2013.

Carpi, A. and Lindberg, S. E.: Application of a Teflon (TM) dynamic flux chamber for quantifying soil mercury flux: tests and results over background soil, Atmos. Environ., 32, 873-882, 1998.

Dorling, S. R., Davies, T. D., and Pierce, C. E.: Cluster-Analysis - a Technique for Estimating the Synoptic Meteorological Controls on Air and Precipitation Chemistry - Results from Eskdalemuir, South Scotland, Atmos. Environ. Part A, 26, 2583-2602, 1992.

Driscoll, C. T., Mason, R. P., Chan, H. M., Jacob, D. J., and Pirrone, N.: Mercury as a global pollutant: sources, pathways, and effects, Environ. Sci. Technol., 47, 4967-4983, doi:10.1021/es305071v, 2013.

Faïn, X., Obrist, D., Hallar, A. G., Mccubbin, I., and Rahn, T.: High levels of reactive gaseous mercury observed at a high elevation research laboratory in the Rocky Mountains, Atmos. Chem. Phys., 9, 8049-8060, doi:10.5194/acp-9-8049-2009, 2009.

Feng, X., Sommar, J., Gårdfeldt, K., and Lindqvist, O.: Improved determination of gaseous divalent mercury in ambient air using $\mathrm{KCl}$ coated denuders, Fresen. J. Anal. Chem., 366, 423-428, 2000. 
Finley, B., Swartzendruber, P., and Jaffe, D.: Particulate mercury emissions in regional wildfire plumes observed at the Mount Bachelor Observatory, Atmos. Environ., 43, 6074-6083, 2009.

Friedli, H., Radke, L., Prescott, R., Hobbs, P., and Sinha, P.: Mercury emissions from the August 2001 wildfires in Washington State and an agricultural waste fire in Oregon and atmospheric mercury budget estimates, Global Biogeochem. Cy., 17, doi:10.1029/2002GB001972, 2003.

Fu, X., Feng, X., Zhu, W., Wang, S., and Lu, J.: Total gaseous mercury concentrations in ambient air in the eastern slope of Mt. Gongga, South-Eastern fringe of the Tibetan Plateau, China, Atmos. Environ., 42, 970-979, 2008.

Fu, X., Feng, X., Dong, Z. Q., Yin, R. S., Wang, J. X., Yang, Z. R., and Zhang, H.: Atmospheric gaseous elemental mercury (GEM) concentrations and mercury depositions at a high-altitude mountain peak in south China, Atmos. Chem. Phys., 10, 2425-2437, doi:10.5194/acp-10-2425-2010, 2010.

Fu, X., Feng, X., Qiu, G., Shang, L., and Zhang, H.: Speciated atmospheric mercury and its potential source in Guiyang, China, Atmos. Environ., 45, 4205-4212, 2011.

Fu, X., Feng, X., Liang, P., Deliger, Zhang, H., Ji, J., and Liu, P.: Temporal trend and sources of speciated atmospheric mercury at Waliguan GAW station, Northwestern China, Atmos. Chem. Phys., 12, 1951-1964, doi:10.5194/acp-12-1951-2012, 2012a.

Fu, X., Feng, X., Shang, L. H., Wang, S. F., and Zhang, H.: Two years of measurements of atmospheric total gaseous mercury (TGM) at a remote site in Mt. Changbai area, Northeastern China, Atmos. Chem. Phys., 12, 4215-4226, doi:10.5194/acp12-4215-2012, 2012b.

Fu, X., Feng, X., Sommar, J., and Wang, S.: A review of studies on atmospheric mercury in China, Sci. Total Environ., 421, 73-81, 2012c.

Gay, D. A., Schmeltz, D., Prestbo, E., Olson, M., Sharac, T., and Tordon, R.: The Atmospheric Mercury Network: measurement and initial examination of an ongoing atmospheric mercury record across North America, Atmos. Chem. Phys., 13, 1133911349, doi:10.5194/acp-13-11339-2013, 2013.

Goodsite, M. E., Plane, J., and Skov, H.: A theoretical study of the oxidation of $\mathrm{Hg}^{0}$ to $\mathrm{HgBr}_{2}$ in the troposphere, Environ. Sci. Technol., 38, 1772-1776, 2004.

Graydon, J. A., St. Louis, V. L., Lindberg, S. E., Hintelmann, H., and Krabbenhoft, D. P.: Investigation of mercury exchange between forest canopy vegetation and the atmosphere using a new dynamic chamber, Environ. Sci. Technol., 40, 4680-4688, 2006.

Guey-Rong Sheu, Neng-Huei Lin, Chung-Te Lee, Jia-Lin Wang, ming-Tung Chuang, Sheng-Hsiang Wang, Kai Hsine Chi, Chang-Feng Ou-Yang: Distribution of atmospheric mercury in northern Southeast Asia and South China Sea during Dongsha Experiment, Atmos. Environ., 78, 174-183, 2013

Iverfeldt, $\AA$. and Lindqvist, O.: Atmospheric oxidation of elemental mercury by ozone in the aqueous phase, Atmos. Environ., 20, 1567-1573, 1986.

Munthe, J., Wängberg, I., Pirrone, N., Iverfeldta A., Ferrara R., Ebinghaus, R., Feng, X., Gardfeldt, K., Keeler, G., Lanzillotta, E., Lindberg, S. E., Luh, J., Mamane, Y., Prestbo, E., Schmolke, S., Schroeder, W. H., Sommar, J., Sprovieri, F., Stevens, R. K., Stratton, W., Tuncel, G., and Urba, A.: Intercomparison of methods for sampling and analysis of atmospheric mercury species, Atmos. Environ., 35, 3007-3017, 2001.
Jaffe, D., Prestbo, E., Swartzendruber, P., Weiss-Penzias, P., Kato, S., Takami, A., Hatakeyama, S., and Kajii, Y.: Export of atmospheric mercury from Asia, Atmos. Environ., 39, 3029-3038, 2005.

Johansson, K., Bergbäck, B., and Tyler, G.: Impact of atmospheric long range transport of lead, mercury and cadmium on the Swedish forest environment, Water, Air Soil Pollut., 1, 279-297, 2001.

Kock, H., Bieber, E., Ebinghaus, R., Spain, T., and Thees, B.: Comparison of long-term trends and seasonal variations of atmospheric mercury concentrations at the two European coastal monitoring stations Mace Head, Ireland, and Zingst, Germany, Atmospheric Environment, 39, 7549-7556, 2005.

Landis, M. S., Stevens, R. K., Schaedlich, F., and Prestbo, E. M.: Development and characterization of an annular denuder methodology for the measurement of divalent inorganic reactive gaseous mercury in ambient air, Environ. Sci. Technol., 36, 3000-3009, 2002a.

Landis, M. S., Vette, A. F., and Keeler, G. J.: Atmospheric mercury in the Lake Michigan basin: Influence of the Chicago/Gary urban area, Environ. Sci. Technol., 36, 4508-4517, 2002 b.

Li, J. and Lee, S. M.: Progress of global atmospheric mercury field observations, J. Clean Energy Technologies, 2, 252-257, doi:10.7763/JOCET.2014.V2.135, 2014.

Lin, C. J. and Pehkonen, S. O.: The chemistry of atmospheric mercury: a review, Atmos. Environ., 33, 2067-2079, 1999.

Lindberg, S.: Forests and the global biogeochemical cycle of mercury: the importance of understanding air/vegetation exchange processes, in: Global and Regional Mercury Cycles: Sources, Fluxes and Mass Balances, Springer, 359-380, 1996.

Lindberg, S. E., Bullock, R., Ebinghaus, R., Engstrom, D., Feng, X., Fitzgerald, W., Pirrone, N., Prestbo, E., and Seigneur, C.: A synthesis of progress and uncertainties in attributing the sources of mercury in deposition, AMBIO: a Journal of the Human Environment, 36, 19-33, 2007.

Lindberg, S. E., Brooks, S., Lin, C.-J., Scott, K. J., Landis, M. S., Stevens, R. K., Goodsite, M., and Richter, A.: Dynamic oxidation of gaseous mercury in the Arctic troposphere at polar sunrise, Environ. Sci. Technol., 36, 1245-1256, 2002.

Lindqvist, O.: Mercury in the Swedish environment: recent research on causes, consequences and corrective methods, Water Air Soil Poll., 55, 1-261, 1991.

Loewen, M., Kang, S., Armstrong, D., Zhang, Q., Tomy, G., and Wang, F.: Atmospheric transport of mercury to the Tibetan Plateau, Environ. Sci. Technol., 41, 7632-7638, 2007.

Mary, M., Lynam, G. and Keeler, J.: Comparison of methods for particulate phase mercury analysis:sampling and analysis, Anal. Bioanal. Chem., 374, 1009-1014, doi:10.1007/s00216002-1584-4, 2002.

Nguyen, H. T., Kim, K. H., Kim, M. Y., Hong, S., Youn, Y. H., Shon, Z. H., and Lee, J. S.: Monitoring of atmospheric mercury at a global atmospheric watch (GAW) site on An-Myun Island, Korea, Water Air Soil Poll., 185, 149-164, 2007.

Obrist, D., Hallar, A., McCubbin, I., Stephens, B. B., and Rahn, T.: Atmospheric mercury concentrations at Storm Peak Laboratory in the Rocky Mountains: evidence for long-range transport from Asia, boundary layer contributions, and plant mercury uptake, Atmos. Environ., 42, 7579-7589, 2008. 
Pacyna, E. G., Pacyna, J. M., Steenhuisen, F., and Wilson, S.: Global anthropogenic mercury emission inventory for 2000, Atmos. Environ., 40, 4048-4063, 2006.

Pfaffhuber, K. A., Berg, T., Hirdman, D., and Stohl, A.: Atmospheric mercury observations from Antarctica: seasonal variation and source and sink region calculations, Atmos. Chem. Phys., 12, 3241-3251, doi:10.5194/acp-12-3241-2012, 2012.

Pirrone, N., Keeler, G. J., and Nriagu, J. O.: Regional differences in worldwide emissions of mercury to the atmosphere, Atmos. Environ., 30, 2981-2987, 1996.

Pirrone, N., Costa, P., Pacyna, J., and Ferrara, R.: Mercury emissions to the atmosphere from natural and anthropogenic sources in the Mediterranean region, Atmos. Environ., 35, 2997-3006, 2001

Pirrone, N., Cinnirella, S., Feng, X., Finkelman, R. B., Friedli, H. R., Leaner, J., Mason, R., Mukherjee, A. B., Stracher, G. B., Streets, D. G., and Telmer, K.: Global mercury emissions to the atmosphere from anthropogenic and natural sources, Atmos. Chem. Phys., 10, 5951-5964, doi:10.5194/acp-10-59512010, 2010.

Poissant, L. and Casimir, A.: Water-air and soil-air exchange rate of total gaseous mercury measured at background sites, Atmos. Environ., 32, 883-893, 1998.

Polissar, A. V., Hopke, P. K., and Harris, J. M.: Source regions for atmospheric aerosol measured at Barrow, Alaska, Environ. Sci. Technol., 35, 4214-4226, 2001.

Qureshi, A., Vadenbo, C., and Hellweg, S.: Anthropogenic mercury flows in India and impacts of emission controls, Environ. Sci. Technol., 47, 8105-8113, doi:10.1021/es401006k, 2013.

Reid, J. S., Hyer, E. J., Johnson, R. S., Holben, B. N., Yokelson, R. J., Zhang, J., Campbell, J. R., Christopher, S. A., Di Girolamo, L., and Giglio, L.: Observing and understanding the Southeast Asian aerosol system by remote sensing: an initial review and analysis for the Seven Southeast Asian Studies (7SEAS) program, Atmos. Res., 122, 403-468, 2013.

Rozwadowska, A., Zielin'ski, T., Petelski, T., and Sobolewski, P.: Cluster analysis of the impact of air back-trajectories on aerosol optical properties at Hornsund, Spitsbergen, Atmos. Chem. Phys., 10, 877-893, doi:10.5194/acp-10-877-2010, 2010.

Seo, Y.-S., Han, Y.-J., Choi, H.-D., Holsen, T. M., and Yi, S.-M.: Characteristics of total mercury (TM) wet deposition: scavenging of atmospheric mercury species, Atmos. Environ., 49, 69-76, 2012.

Schroeder, W. H. and Munthe, J.: Atmospheric mercury-an overview, Atmos. Environ., 32, 809-822, 1998.

Schwesig, D. and Krebs, O.: The role of ground vegetation in the uptake of mercury and methylmercury in a forest ecosystem, Plant Soil, 253, 445-455, 2003.

Sharma, D. C.: Concern over mercury pollution in India, Lancet, 362, 1050, doi:10.1016/S0140-6736(03)14456-X, 2003.
Sheu, G.-R., Lin, N.-H., Lee, C.-T., Wang, J.-L., Chuang, M.-T., Wang, S.-H., Chi, K. H., and Ou-Yang, C.-F.: Distribution of atmospheric mercury in northern Southeast Asia and South China Sea during Dongsha Experiment, Atmos. Environ., 78, 174-183, 2013.

Sprovieri, F., Gratz, L., and Pirrone, N.: Development of a Ground-Based Atmospheric Monitoring Network for the Global Mercury Observation System (GMOS), E3S Web of Conferences, 17007, Rome, Italy, 22-27 September 2012, doi:10.1051/e3sconf/20130117007, 2013.

Steffen, A., Bottenheim, J., Cole, A., Ebinghaus, R., Lawson, G., and Leaitch, W. R.: Atmospheric mercury speciation and mercury in snow over time at Alert, Canada, Atmos. Chem. Phys., 14, 2219-2231, doi:10.5194/acp-14-2219-2014, 2014.

Streets, D. G., Hao, J., Wu, Y., Jiang, J., Chan, M., Tian, H., and Feng, X.: Anthropogenic mercury emissions in China, Atmos. Environ., 39, 7789-7806, 2005.

Sunderland, E. M., Krabbenhoft, D. P., Moreau, J. W., Strode, S. A., and Landing, W. M.: Mercury sources, distribution, and bioavailability in the North Pacific Ocean: insights from data and models, Global Biogeochem. Cy., 23, doi:10.1029/2008GB003425, 2009.

Valente, R. J., Shea, C., Lynn Humes, K., and Tanner, R. L.: Atmospheric mercury in the Great Smoky Mountains compared to regional and global levels, Atmos. Environ., 41, 1861-1873, 2007.

Wang, B. and Fan, Z.: Choice of South Asian summer monsoon indices, B. Am. Meteorol. Soc., 80, 629-638, 1999.

Wang, B., Wu, R., and Lau, K.: Interannual Variability of the Asian Summer Monsoon: contrasts between the Indian and the western North Pacific-East Asian Monsoons*, J. Climate, 14, 40734090, 2001.

Wang, Q., Shen, W., and Ma, Z.: Estimation of mercury emission from coal combustion in China, Environ. Sci. Technol., 34, 2711-2713, 2000

Wang, Y. Q., Zhang, X. Y., and Draxler, R. R.: TrajStat: GIS-based software that uses various trajectory statistical analysis methods to identify potential sources from long-term air pollution measurement data, Environ. Model. Softw., 24, 938-939, 2009.

Xiao, Z., Sommar, J., Wei, S., and Lindqvist, O.: Sampling and determination of gas phase divalent mercury in the air using a $\mathrm{KCl}$ coated denuder, Fresen. J. Anal. Chem., 358, 386-391, 1997.

Xu, B., Cao, J., Hansen, J., Yao, T., Joswia, D. R., Wang, N., Wu, G., Wang, M., Zhao, H., and Yang, W.: Black soot and the survival of Tibetan glaciers, P. Natl. Acad. Sci. USA, 106, 22114-22118, 2009.

Yang, Y., Chen, H., and Wang, D.: Spatial and temporal distribution of gaseous elemental mercury in Chongqing, China, Environ. Monit. Assess., 156, 479-489, 2009.

Zhang, Q., Huang, J., Wang, F., Mark, L., Xu, J., Armstrong, D., Li, C., Zhang, Y., and Kang, S.: Mercury Distribution and Deposition in Glacier Snow over Western China, Environ. Sci. Technol., 46, 5404-5413, 2012. 